http://openjournal.wdh.ac.id/index.php/edudharma

Edu Dharma Journal

ISSN (Print) 2597-890 X , ISSN (Online) 2686-6366



\title{
STATUS GIZI TERHADAP USIA MENARCHE PADA SELURUH SISWI DI SMP NEGERI 5 PASAR KEMIS KABUPATEN TANGERANG
}

Bambang Mardisentosa $^{1}$, Septi Nurhasanah ${ }^{2}$, Ayu Pratiwi $^{3}$, Dewi Nur Puspita Sari ${ }^{4}$, Imas Sartika ${ }^{5}$ ${ }_{1,2,3,4,5}$ STIKes Yatsi Tangerang, jl.Aria Santika Margasari, No 40A Bugel Karawaci Kota Tangerang-Banten 15113

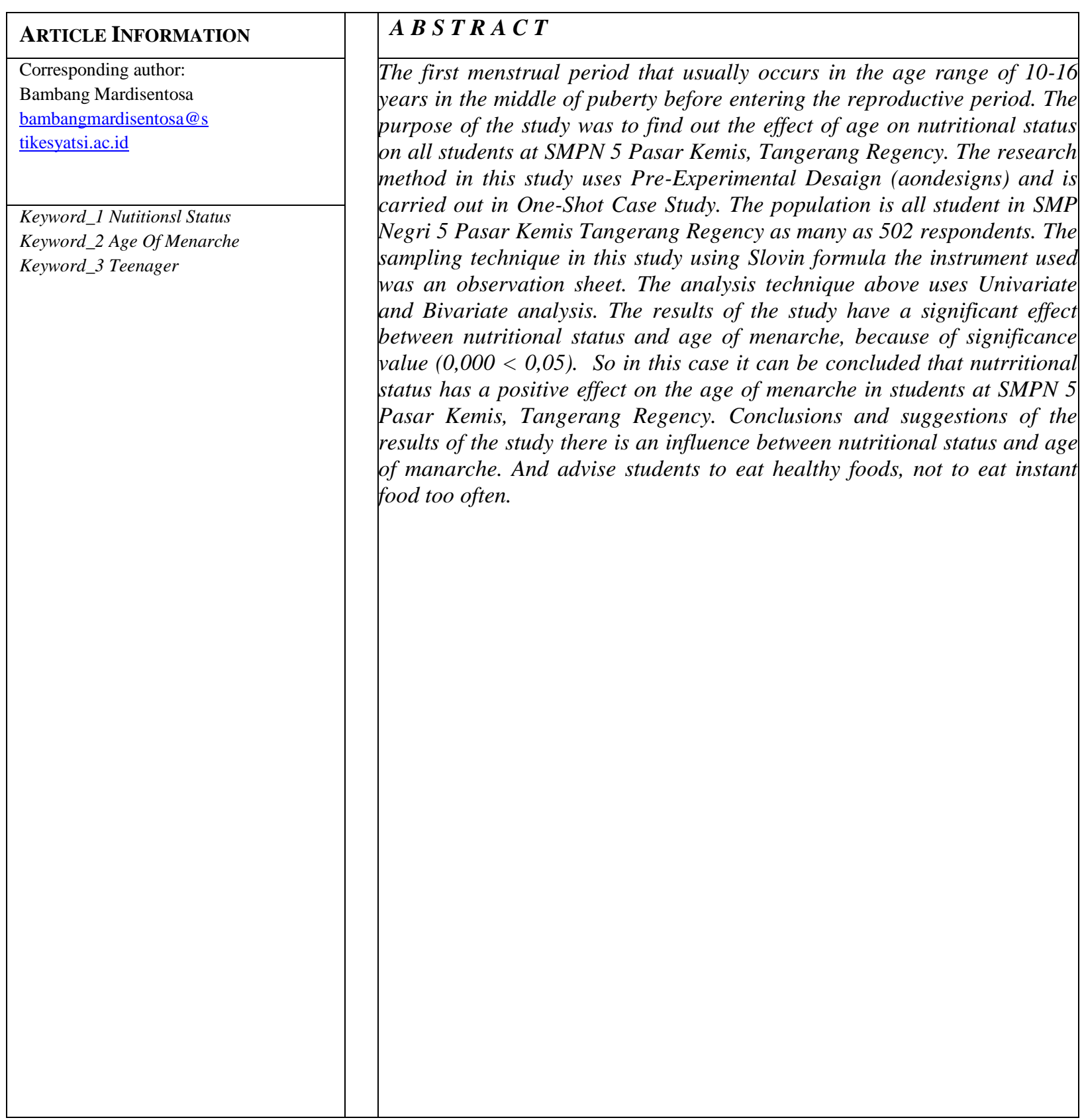




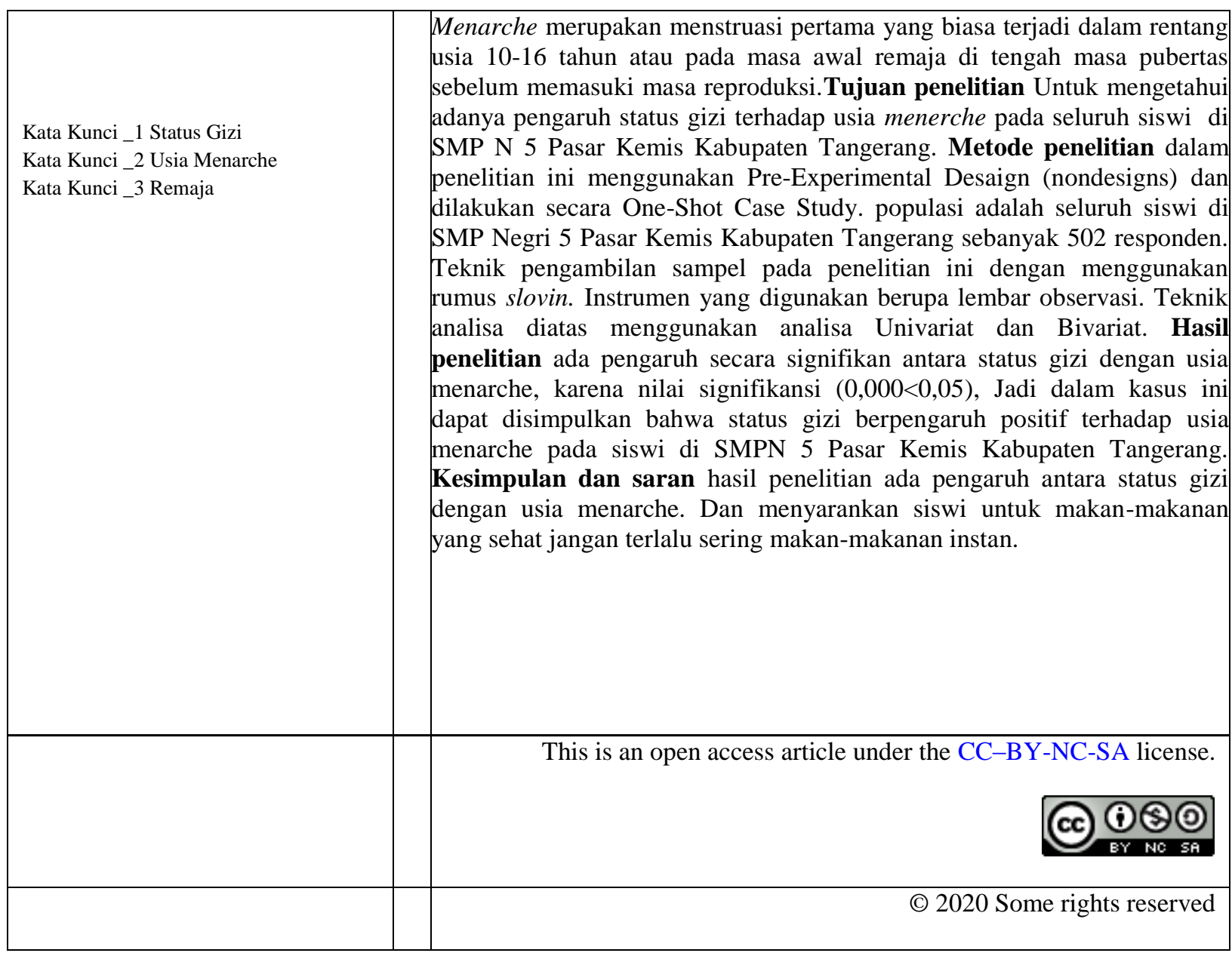




\section{PENDAHULUAN}

Menurut World Health Organization (WHO) Remaja merupakan individu yang memiliki batasan usia 10-19 tahun. United Nations Internasional Children's Fund (UNICEF) menyatakan usia remaja adalah antara 10 sampai 19 tahun, sedangkan menurut Depkes RI (2014) menyimpulkan remaja adalah antara 1019 tahun dan belum menikah (Abadi Dewi Nurcahyati, 2015).

Di dunia diperkirakan kelompok remaja berjumlah 1,2 milyar atau $18 \%$ dari jumlah penduduk dunia (WHO, 2014). Sedangkan di Indonesia terdapat $26,67 \%$ (63,4 juta jiwa) remaja dan sebanyak $49,30 \%$ berjenis kelamin perempuan (BKKBN, 2011). Data dari Badan Pusat Statistik (BPS) Pemerintah Provinsi Banten 2015 menunjukan jumlah remaja berjenis kelamin perempuan usia 1014 tahun 508.324 jiwa, usia 15-19 tahun 513.195 jiwa.

Masa remaja merupakan tahapan antara masa kanak-kanak dengan masa dewasa yang terjadi antara usia 10 hingga 19 tahun. Sebelum memasuki masa remaja seorang anak akan mengalami suatu periode yang dinamakan pubertas terlebih dahulu. Masa pubertas dalam kehidupan kita biasanya dimulai saat berumur 8 hingga 10 tahun dannberakhir lebih kurang di usia 15 hingga 16 tahun.

Masa pubertas pada wanita ditandai dengan pertumbuhan fisik yang cepat, menarche, perubahan psikologis dan timbulnya ciri-ciri kelamin sekunder. $124 \mid$ P a g
Pubertas pada remaja putri ditandai dengan datangnya menstruasi untuk pertama kalinya yang dikenal dengan istilah menarche. Respon remaja putri saat mengalami menarche sangat bervariasi, terdapat remaja yang berespon positif tetapi mayoritas yang berespon negatif (Mansur, 2009).

Menarche adalah haid atau menstruasi yang pertama kali dialami oleh seseorang wanita dan terjadi ditengah masa pubertas sebelum memasuki masa reproduksi (Aulia, 2009). Menarche merupakan menstruasi pertama yang biasa terjadi dalam rentang usia 10-16 tahun atau pada masa awal remaja di tengah masa pubertas sebelum memasuki masa reproduksi (Proverawati, 2009).

Faktor rendahnya asupan serat dan tingginya asupan lemak maupun kalsium berdampak pada usia menarche dini (Susanti, 2012). Kekurangan gizi pada remaja mengakibatkan terhambatnya kesehatan reproduksinya termasuk perkembangan dari masa pubertasnya. Kecepatan menarche di bantu dengan pemenuhan gizi yang cukup dimana dengan gizi yang baik membantu pertumbuhan organ-organ reproduksi remaja (Widyastuti, 2009). Menurut Kusnita dan Damarati (2012) Percepatan proses menarche juga dipengaruhi oleh perubahan hormon steroid estrogen da dan progesteron yang mempengaruhi pertumbuhan endometrium, semakin baik gizi siswi maka semakin cepat siswi akan mengalami menarche.

Upaya pemerintah melalui UU No. 10 tahun 1992, yaitu : menjamin terselenggaranya hakhak yang sama dalam kesehatan reproduksi. Kebijakan teknis pemerintah di dalam kesehatan reproduksi remaja antara lain : peningkatan advokasi kesehatan reproduksi, peningkatan kegiatan remaja, pengembangan KIE (komunikasi, informasi, edukasi) kesehatan 
reproduksi remaja, peningkatan konseling kepada remaja yang membutuhkan, peningkatan dukungan pelayanan bagi remaja yang memiliki masalah khusus serta peningkatan dukungan bagi kegiatan remaja yang positif (BKKBN, 2001).

\section{METODE}

Dalam penelitian mengenai "pengaruh status gizi terhadap usia menarche pada seluruh siswi di SMPN 5 Pasar kemis kabupaten Tangerang menggunakan desain penelitian Pre-Experimental Desaign (nondesigns) dan dilakukan secara One-Shot Case Study.yaitu penelitian yang bertujuan untuk mencari pengaruh perlakuan tertentu dan selanjutnya diobservasi hasilnya. (perlakuan adalah sebagai variable independent dan hasil adalah sebagai variable dependen).

\section{HASIL}

Tabel 1. Distribusi frekuensi responden berdasarkan status gizi di SMP N 5 Pasar Kemis Kabupaten Tangerang

\begin{tabular}{rlll}
\hline No & Status gizi & Jumlah & Persentase \\
\hline 1. & Kurus & 28 & $33,7 \%$ \\
2. & Normal & 33 & $39,8 \%$ \\
3. & Gemuk & 22 & $26,5 \%$ \\
\hline Total & & 83 & $100 \%$ \\
\hline
\end{tabular}

Berdasarkan hasil penelitian Status Gizi yang dilakukan di SMPN 5 Pasar Kemis Kabupaten Tangerang bahwa mayoritas status gizi yaitu kurus sebanyak 28 orang $(33,7 \%)$. Normal sebanyak 33 orang $(39,8 \%)$, dan Gemuk sebanyak 22 orang $(26,5 \%)$.
Tabel 2. Distribusi frekuensi responden berdasarkan usia menarche di SMP N 5 Pasar Kemis Kabupaten Tangerang

\begin{tabular}{llll}
\hline No. & Usia menarche & Jumlah & $\%$ \\
\hline 1. & 19 thn & 4 & $4,8 \%$ \\
\hline 2. & 11 thn & 19 & $22,9 \%$ \\
\hline 3. & 12 thn & 49 & $59,0 \%$ \\
\hline 4. & 13 thn & 9 & $10,8 \%$ \\
\hline 5. & 14 thn & 2 & $2,5 \%$ \\
\hline 6. & 15 thn & 0 & $0 \%$ \\
\hline 7. & 16 thn & 0 & $0 \%$ \\
\hline Total & & 83 & $100 \%$ \\
\hline
\end{tabular}

Berdasarkan hasil penelitian yang dilakukan di SMPN 5 Pasar Kemis Kabupaten Tangerang dapat disimpulkan bahwa mayoritas usia menarche yaitu usia 10 tahun sebanyak 4 orang $(4,8 \%)$, usia 11 tahun sebanyak 19 orang $(22,9 \%)$, usia 1 tahunsebanyak 49 orang $(59,0 \%)$, usia 13 tahun sebanyak ada 9 orang (10,8\%), usia 14 tahun sebanyak 2 orang (2,5 $\%)$, sedangkan usia 15 tahun dan 16 tahun 0 $\%$.

Tabel 3. Distribusi regresi sederhana tabel anova pengaruh status gizi terhadap usia menarche pada seluruh siswi pada SMPN 5 Pasar Kemis.

\begin{tabular}{llllll}
\hline & Sum of & & Mean & & \\
Model & Squares & Df & Square & F & Sig. \\
\hline Regression & 7,476 & 1 & 7,476 & 14,363 &, 000 \\
Residual & 42,162 & 81 &, 521 & & \\
\hline Total & 49,639 & 82 & & & \\
\hline
\end{tabular}

Berdasarkan hasil dari tabel ANOVA diatas menjelaskan apakah ada pengaruh yang nyata (signifikan) variabel status gizi $(\mathrm{X})$ terhadap variabel usia menarche $(\mathrm{Y})$ dari output tersebut terlihat bahwa F hitung 14,363 dengan tingkat signifikasi/probabilitas 0,000Q< 0,05 maka model regresi dapat dipakai untuk memprediksi variabel usia menarche. 
Tabel 4. Korelasisederhana pengaruh status gizi terhadap usia menarche pada seluruhsiswi pada SMPN 5Pasar Kemis Kabupaten Tangerang

\begin{tabular}{cccc}
\hline Status gizi & $\begin{array}{c}\text { Pearson } \\
\text { Correlation }\end{array}$ & $\begin{array}{c}\text { Status } \\
\text { gizi }\end{array}$ & $\begin{array}{c}\text { Usia } \\
\text { menarche }\end{array}$ \\
\hline & Sig. (2-tailed) & 0,388 &
\end{tabular}

Usia menarche Sig. (2-tailed)

(sumber: Data Primer, 2019)

Dari hasil analisa korelasi sederhana

didapat korelasi antara status

dengan usia menarche adalah 0,388.

Hal ini menunjukan bahwa terjadi

hubungan yang kuat antara status

gizi dengan usia menarche. sedangkan

hubungan adalah positif karena nilai positi

f,berarti semakin baik setatus gizi semakin

cepat pula usia menarche. Berdasarkan

hasil penelitian yang dilakukan di SMPN 5

Pasar Kemis Kabupaten Tangerang bahwa mayoritas status gizi yaitu Kurus sebanyak 28 orang $(33,7 \%)$, Normal sebanyak 33 orang $(39,8 \%)$, dan Gemuk sebanyak 22 orang $(26,5 \%)$.

Berdasarkan hasil penelitian yag dilakukan di SMPN 5 Pasar Kemis Kabupaten tangerang dapat disimpulkan bahwa mayoritas usia menarche yaitu usia 10 tahun sebanyak 4 orang $(4,8 \%)$, usia 11 tahun sebanyak 19 orang $(22,9 \%)$, usia 12 tahun sebanyak 49 orang $(59,0 \%)$, usia 13 tahun sebanyak 9 orang $(10,8 \%)$, usia 14 tahun sebanyak 2 orang $(2,5 \%)$, sedangkan usia 15 tahun dan 16 tahun $0 \%$.

\section{PEMBAHASAN}

Berdasarkan hasil penelitian yang dilakukan di SMPN 5 Pasar Kemis Kabupaten Tangerang bahwa mayoritas status gizi yaitu Kurus sebanyak 28 orang $(33,7 \%)$, Normal sebanyak 33 orang $(39,8 \%)$, dan Gemuk sebanyak 22 orang (26,5\%). Karena kebutuhan gizi setiap orang berbeda-beda misalnya seperti untuk remaja usia 12-15 tahun membutuhkan protein sebesar 62 gr dan energi sebesar $2100 \mathrm{kal}$, sedangkan untuk usia 16-19 tahun membutuhkan protein sebesar $51 \mathrm{gr}$ dan energi sebesar 2000 kal. Pada abad ini secara umum ada pergeseran permulaan pubertas kearah umur yang lebih muda dikarenakan meningkatnya kesehatan umum dan gizi. Kekurangan gizi pada remaja mengakibatkan terhambatnya kesehatan reproduksinya termasuk perkembangan dari masa pubertasnya. Kecepatan menarche di bantu dengan pemenuhan gizi yang cukup dimana dengan gizi yang baik membantu pertumbuhan organ-organ reproduksi remaja (Widyastuti, 2009).

Berdasarkan hasil penelitian yag dilakukan di SMPN 5 Pasar Kemis Kabupaten tangerang dapat disimpulkan bahwa mayoritas usia menarche yaitu usia 10 tahun sebanyak 4 orang $(4,8 \%)$, usia 11 tahun sebanyak 19 orang $(22,9 \%)$, usia 12 tahun sebanyak 49 orang $(59,0 \%)$, usia 13 tahun sebanyak 9 orang $(10,8 \%)$, usia 14 tahun sebanyak 2 orang $(2,5 \%)$, sedangkan usia 15 tahun dan 16 tahun $0 \%$.

Berdasarkan analisa bivariat pengauh Status gizi terhadap usia menarche dari uji normalitas berdasarkan table 4 hasil dari distribusi tersebut diperoleh nilai signifikasi statusgizi 0,221 dan nilai signifikasi usia menarche dari table di atas yaitu 0,309. Berdasarkan hasil tersebut maka dapat disimpulkan bahwa data status gizi dan usia menarche berdistribusi normal $(\mathrm{p}>0,05)$ sehingga $126 \mid \mathrm{P}$ ag semua variable baik, variable bebas maupun 
variable terikat pada penelitian ini berdistribusi normal, maka analisa regresi dapat dilanjutkan.

\section{KESIMPULAN}

Distribusi frekuensi analisa univariat status gizi telah diteliti terhadap 83 responden menghasilkanga gambarkan sebagian mayoritas status gizi yaitu Kurus sebanyak 28 orang $(33,7 \%)$, Normal sebanyak 33 orang $(39,8 \%)$, dan Gemuk sebanyak 22 orang (26,5\%).

Distribusi frekuensi analisa univariat untuk usia menarche yaitu usia 10 tahun sebanyak 4 orang $(4,8 \%)$, usia 11 tahun sebanyak 19 orang $(22,9 \%)$, usia 12 tahun sebanyak 49 orang $(59,0 \%)$, usia 13 tahun sebanyak 9 orang $(10,8 \%)$, usia 14 tahun sebanyak 2 orang (2,5\%), sedangkan usia 15 tahun dan 16 tahun $0 \%$.

Distribusi berdasarkan Pengaruh Status Gizi Terhadap Usia Menarche di SMPN5 Pasar Kemis Kabupaten Tangerang adalah status gizi berhubungan positif dan signifikan tehadap usia menarche. Jadi dalam kasus ini dapat disimpulkan bahwa status gizi berhubungan positif terhadap usia menarche pada siswi di SMPN 5 Pasar Kemis Kabupaten Tangerang.

Bagi remaja putri untuk menambah wawasan khususnya untuk remaja putri mengenai pengaruh status gizi terhadap usia menarche,
Bagi peneliti selanjutnya diharapkan agar dalam menyususn parameter penilaian tidak hanya menerapkan status gizi dan usia menarche tetapi juga dengan faktor-faktor lain yang dapat mempengaruhi status gizi dan usia menarche di sekolah-sekolah dan dilingkungan masyarakat. Menyediakan sumbersumber kepustakaan lebih banyak dan terbaru yang berkaitan dengan status gizi dan usia menarche sehingga memudahkan untuk mengembangkan penelitian melalui literratur-literatur yang bervariasi.

\section{DAFTAR PUSTAKA}

Purba Devi RR. 2015. Resiliensi Narapidana Dewasa di Lembaga Pemasyarakatan Klas IIA Sragen.

Anik Malikahah. 2013. Hubungan Status Gizi Dengan Usia Menarche pada Remaja Putri di SMP Negri 01 Pringapus Kabupaten Semarang.

Fahmi Fuadah. 2016. Hubungan Status Gizi dengan Usia Menarche Dini pada Remaja Putri di SMP Umi Kulsum Banjaran Kab. Bandung Provinsi Jawa Barat

Hemi Fitriani, Riryn Yulia Rohman. 2016. Pengaruh Konseling Terhadap Kecemasan Remaja Putri yang Mengalami Menarche.

Icemi Sukarni K, Wahyu P. 2013. Buku ajaran keperawatan maternitas, Yogyakarta : Nuha Medika

Dewa Nyoman Suparasia, Bachyar Bakri, dan Ibnu Fajar. 2012. Penilian status gizi. editor, Monica. Jakarta: EGC

Lenny Irawati. 2013. Hubungan Pengetahuan Tentang Menarche dengan Tingkat Kecemasan pada Remaja Putri di SMPN Tambun Selatan Tahun 2013.

Lestari,T. 2015. Kumpulan Teori Untuk Kajian Pustaka Penelitian Kesehatan. Yogyakarta: Nuha Medika 
Ning Setiowati. 2015. Hubungan Dukungan Ibu dengan Kesiapan Menghadapi Menarche pada Siswi Kelas V dan VI MI Muhammadiyah Bonjor Tretep Temanggung.

Notoatmodjo, Soekidjo. 2012. Metodologi Penelitian Kesehatan.Jakarta : Rineka Cipta

Syamsu Yusuf . 2016.Psikologis perkembangan anak dan remaja. Bandung : PT REMAJA ROSDAKAYA

Sugiyono. 2015. Metode Penelitian Kuantitatif Kualitatif Dan R\&D. Bandung: Alfabeta

Rahmat Nurul Putra Yuda, Ermawati, Arni Amir. 2014. Hubungan Indek Massa Tubuh (IMT) dengan Usia Menarche pada Siswi SMP 1 Padang.

Rika Herawati. 2013. Faktor-Faktor yang Berhubungan dengan Usia Menarche pada Remaja Putri di SMP 8 Tambunsai Utara tahun 2013.

Sarah Stevany Munda, Freddy W Waege, Jhon Watania,2012. Hubungan Antara IMT dengan Usia Menarche pada Siswi SD dan SMP di Kota Manado.

Septiana Wulandai. 2013. Satus Gizi, Aktivitas Fisik dan Usia Menarche Remaja Putri.

Sumy Dwi Antono. 2014. Hubungan Antara Status Gizi (IMT) dengan Usia Menarche pada Remaja Putri Usia 1314 Tahun di SMP 1 Pace Kecamatan Pace Kabupaten Nganjuk.

Syilvia V, Fitria Saftarina. 2012. Hubungan Status Gizi dengan Usia Menarche Pada Remaja Putri di SMP Negri 22 Bandar Lampung. 